DOI https://doi.org/10.18551/rjoas.2018-06.09

\title{
GOVERNANCE AND ORGANIZATIONAL CULTURE: AN ETHNOGRAPHIC STUDY ON INDONESIAN POLITICAL PARTY
}

\author{
Rahayu Sovi Ismawati* \\ Faculty of Economics, YARSI University, Jakarta \& Doctoral Program in Accounting, Faculty \\ of Economics and Business, University of Brawijaya, Indonesia \\ Ludigdo Unti, Irianto Gugus, Prihatiningtias Yeney Widya \\ Faculty of Economics and Business, University of Brawijaya, Indonesia \\ *E-mail: sovi.ismawati@yarsi.ac.id
}

\begin{abstract}
The objectives of this research were to understand and describe the essence of Good Party Governance (PGP) in Prosperous Justice Party (PKS) based on its culture. That research goals were achieved using interpretive paradigms as Spradley's ethnography foothold and method with advanced gradual research flows. The reason to choose PKS as the research object was according to the result of ICW's study, PKS has the best governance among political parties of general election attendee in 2014. Research informants were representative from the Majelis Syuro (religious council), the Central Advisory Assembly, the Sharia Council Center, and the Council of Central Committee amounted to 8 people. The results revealed that the spirit of Ihsan as GPG essence in PKS, which is performing a duty as well, as beautiful, and as perfect as possible as a form of faith and love to Allah the God Almighty. PKS applied the ihsan spirit to the party governance by establishing the foundation and elements of GPG: Party Paradigm, Basic Philosophy of Struggle, Policy Principles and Development Policy Platform, Management System of Dakwah Party, Strategic Planning (Renstra), and Annual Working Plan Budget. According to the research result, in the theoretical realm it functions as the development of good governance concept in political parties, in the practical realm it functions as a comparison of good governance practice in political parties and in the policy realm it functions as a matter of consideration by the government in reviewing and improving the rules related to Good Party Governance.
\end{abstract}

\section{KEY WORDS}

Good governance, political parties, ethnography, ihsan.

The era of reform gives hope in the discourse on the urgency of good governance in the conceptual review conducted by World Bank (1992), UNDP (1997), and Raba (2006). The form of good governance according to the National Institute of Public Administration (LAN) is a solid and responsible as well as efficient and effective country governance by maintaining the "synergistic" of constructive interaction between the country domains, the private sector and society (Widodo, 2001). The World Bank sets the limits of good governance as an efficient public service, a reliable judicial system, and a government that is publicly accountable. Gerald Meier defines good governance as "a principle to organize the government that enables efficient public services, a reliable court system, and its administration is publicly accountable, and for which market mechanisms are a major consideration in the decision-making process of resource allocation "(Abdullah, 2002).

In terms of realizing Good Governance, there are three main principles to follow. Firstly, accountability principle, this means an ability to make a policy, starting from decisionmaking process and policy socialization stage. Secondly, the principle of transparency is a principle that guarantees an access or freedom for everyone to obtain governance information, information on policies, its decision-making, and the results achieved. Thirdly, participation principle, that everyone is entitled to be involved in decision-making of every 
governance activity. This participation is to strengthen democracy, to improve the quality and the effectiveness of public services.

One of the organizations being in the spotlight at society related to the good governance is a political party, because in the context of democracy and regional autonomy, the existence of political parties is important for good governance. Good Governance is able to achieve by realizing GPG in advance as it can be the basis for Good Governance and Good Corporate Governance. Good management of a party will be able to produce high-integrity political elite to formulate good political policies as a reference of good governance. Therefore, it needs a real and strong effort to build GPG in the political party environment as a foundation to establish and realize good governance. Political parties become a society's remote control for good governance and well management.

To Establish Good Party Governance means to create an organizational system of a party to be accountable, and to set the actors out of the party to play a role in creating a useful new system in general. Building a GPG is a great social project and to be realistic, that project should be done gradually. The main problem of the realization of GPG lies in the individual role, the awareness of the actor in creating a good and fair political climate. Therefore, it needs political leaders with a good track record, high integrity and strong leadership character.

Shakil's (2013) research on Bangladesh perspective of political parties and good governance states that, to establish good governance and democracy, there is no way except fixing the fault of political parties. Democracy and good governance is a synonym. In order to maintain democracy and good governance in a country, it needs to develop the application of good governance within the political party in advance. Otherwise, people cannot expect good governance if the party is in power. We must pay attention to make that type of good governance platform on political parties' side to ensure good governance as this is the easiest way to fulfill our desire to develop as a nation.

Islam (2016) studying the realities of good governance and political culture in a case study in Bangladesh reveals that the current political culture is winning elections in whatever way it takes to stay in power and attacking the opponent, so it is necessary to address and improve the cultural properties of the political party by preventing it through the good governance in the political party. Similarly, Chikerema's (2014) study on Zimbabwe's political culture and democratic governance, that scientists ignore the relationship of political culture and democratic governance. However, in Africa was found that the African political landscape with mutilation culture and good governance has also been mutilated. Political culture is essential and crucial for the ideal practice of democracy, democratic governance highly depends on the political culture in a Country, and Zimbabwe is responsible for political issues because of the kind of political culture it has. Musa (2016) explained that in relation to the democratic problem, political party and good governance state that democratic institution must be strengthened through a proper and independent funding to promote democracy and good governance.

Some of studies above show that the realization of good governance can be started by correcting political party governance and that governance are influenced by the existing political culture. However, this study examines the organizational culture in one political party in Indonesia which ultimately raises the interpretation of good governance and its implementation which is loaded with the underlying values of political organization. This study aims to describe the essence of Good Party Governance and how its implemented in a political party, analyzed and explored from view, ideology, culture and values owned and attached to political parties being the research object by ethnographic methods. The object of this research is the Prosperous Justice Party (PKS). A consideration to choose PKS is due to this political party is one of the parties being the general election attendee in 2014 and its governance and transparency are considered the best based on the 2015 study of Indonesia Corruption Watch (ICW). According to that background, this article will fatherly describe the methods applied to achieve the research objectives. The next section is the results and discussion as well as conclusions consisting of a summary of research, limitations, and implications of subsequent research. 


\section{METHODS OF RESEARCH}

To describe the meaning of Good Party Governance in PKS, this research applied an interpretive paradigm as a foothold. The interpretive paradigm used as a foothold in this study was to focus on the subjective nature of the actor and to understand theoretical framework of the investigated object. In order to understand a specific social environment like PKS, the researchers must explore the subjective experience of the actors.

According to Spradley (1997), ethnography was an activity to describe the culture of a particular society or community. The main purpose was to understand the way people live from society or that community's perspective. Qualitative research using an ethnographic approach aimed to have thick descriptions and to make an interpretation towards the subjective meaning of culture, traditions, and daily habits of a group of investigated subjects. Ethnographic research led to the meaning of action, which was directed to the meaning of action itself in an ethnic, tribal, group, community, or an institution that cannot be separated from historical tradition.

Collection procedure and ethnographic data analysis in search of the essence of Good Party Governance in PKS utilized 12 stages of Spradeley's "Advanced Gradual Research Flows (1997)." Those twelve steps were: Assigning informants, Interviewing informants, Making ethnographic notes, Asking descriptive questions, Conducting analysis of ethnographic interview results, Making domain analysis, Asking structural questions, Making taxonomic analysis, Asking contrast questions, Making component analysis, Finding cultural themes, and Writing the result of ethnographic study.

This study utilized three sources of ethnographic data: 1) Informants perspective dug deeper from eight informants from MS, MPP, DPP and DSP elements, 2) Field notes related to the cultural atmosphere which was the result of observation and interaction of the researchers in the site with participant observation and 3) Artifacts obtained and collected by the researcher as supporting material in making analysis were: Articles of Association and Bylaws, Strategic Planning (Renstra), Annual Work Plan Budget (RKAT), Fatwa and Bayan of DSP, Financial Statements, BPK Audit Reports, Statement Letter of Councilor Membership Fee (IWAD), Core Membership Fee (IWAI), fifty-thousand-rupiahs movement, Financial Statements Application.

Ethnographic analysis conducted to find cultural themes was Firstly, domain analysis to identify a list of domains that will provide an insight into the cultural atmosphere, secondly, taxonomic analysis to reveal the internal structure of the chosen domain, and thirdly, component analysis to more systematically identify various essence components in the original terms of informants

Domain analysis result above yields three hypothesized domains. Those three domains were: 1) The way to give respect of the Dakwah Party covers to: The Cultural Dakwah, Structural Dakwah, and Ihsan spirit; 2) The elements of Good Party Governance include: Basic Philosophy, Policy Principles, Platforms, Management System of Dakwah Party (SMPD), Strategic Planning (Renstra), and Annual Work and Budget Plan (RKAT); and 3) The meaning of Clean, Caring, Professional in its slogan includes: Personally religious, socially religious, and working with itqon work ethic. Those domains provide insights into the cultural atmosphere of PKS to describe a holistic view of PKS.

This research would select one domain based on the research objectives studied, which was "Good Party Governance" domain. The next stage, the researchers would use the domain to perform taxonomic analysis and component analysis to find cultural themes in GPG PKS. Other domains would be supporters and complete the discussion of the main domain. The results of the taxonomy analysis provided more detailed information of the internal structure of the domain "Good Party Governance elements". The Basic Philosophy has an internal structure: Islam and civil society. Policy Principle has an internal structure: ten principles. Platform has an internal structure, they were; Vision, Mission, Program, and Attitude. Management System of Dakar Party (SMPD) has an internal structure: Performance and OKA Bureau. Strategic Planning (Rostra) has internal structure: Definitions, Methods, and Processes. Annual Work Plan Budget (RKAT) has an internal structure: Processes, 
Programs and Budgets. This taxonomic analysis also found a new relationship among the various original terms informants that have been used in the analysis of the previous domain. Domain analysis and taxonomic analysis seek a resemblance between the original terms of the informant, which would be followed by a component analysis to focus on the differences or contrasts in order to find the component of essence/attribute.

Based on the results of the component analysis, it was known the differences of the existing contrast circuit. The difference was in terms of nature, time, and form. The difference of that set of contrast provides a component of essence/attribute in the contrast circuit. Basic Philosophy shapes paradigm and Policy Principle shapes a temporal policy, while the platform shaped guidance is more temporal, SMPD shapes simultaneous operational management, and Strategic Planning was a five-year strategic program period of and described in RKAT shaped working program implemented annually.

The cultural theme for the purpose of ethnographic research was the cognitive principle (something that people believe and accept as valid and true/a general assumption about their experience) that was implied or explicit (looks like a proverb, motto, saying or repeated expression), recurring in a number of domains and acting as a link between various subsystems of cultural significance, acting as a general semantic relation among various domains. According to the domain analysis, taxonomic analysis, and componential analysis above, it found cultural themes in Good Party Governance of PKS which was Ihsan spirit, Basic Philosophy of Struggle, Development Policy Platform, Management System of Dakwah Party (SMPD), Strategic Planning (Renstra), and Annual Budget Work Plan (RKAT).

\section{RESULTS AND DISCUSSIONS}

This section will describe the research results and discussion consisting of two parts, namely: the essence of good party governance for PKS and the foundation and elements in good party governance of PKS.

Ihsan Spirit in Managing Party to Achieve Good Party Governance. PKS is not just a forum of political struggle as defined by Law Number 2 Year 2011 on the amendment to Law Number 2 Year 2008 regarding Political Parties. PKS calls itself as a Dakwah Party that strives for structural and cultural values of Islam. Dakwah is structurally conducted through political channels. It covers to legislation activity, presenting laws, government regulations or other public policies. The struggle of Islamic values is culturally conducted by cadres and strategic partners of PKS through various dakwah media and cultural institutions to strengthen the cultural base and intellectuality of the ummah to encourage the vertical mobility of people in various fields whether bureaucracy, economy, culture, intellectual, social and political.

Learning from the journey and experience of PKS during this time, PKS always try to improve itself which is confirmed by the realization of Good Party Governance in one missions formulated by PKS. One of the efforts is to invite PPATK and CSIS at the 2016 moderns (national working meeting) to discuss about political party funding. This was stated by former Vice Chairman of PKS, as follows:

"Firstly, we have a Good Party Governance (GPG) program; it is our attempt to be a modern, accountable, transparent, and participative party. Therefore, we as the committee agreed to have to attend either KPK or PPATK. Hence, we proposed, Pak Sohibul Iman agreed to invite PPATK and Pak Muhammad Yusuf came as the representation, he explained about the practices of political parties funding from the results of PPATK monitoring on how it works. He gave a lot of input that the point is that the more transparent a party, the higher the public trust, if the public trust high so is the public funding (MAS)".

One of the efforts undertaken for good governance in PKS is to improve the accountability and transparency of the Party primarily related to financial management. According to Rosenbaum (2003), there is no more central issue regarding good governance than accountability concepts. That effort has made PKS to get appreciation or something like a transparency reward from Public Information Committee (PIC). 
"Because from 10 political parties being there in the House of Representatives (DPR), it was only four which submit and hand over the report. It's also better than the previous year which was only three. It actually cannot be used as a standard so it return directly will get appreciation (DSU)".

In addition, PKS is also open to public related to Party's Financial Report, by inviting people who want to access for research purposes and so on by coming to the office of DPP PKS and requesting public data to PR, as stated by PKS Public Relation Chair:

"We are quite open to the public, for those who want to know the party's financial statements, we invite to access it, but they have to come here. It might become our concern to launch it on the website to ease society. But for the interested parties or the public, who wants to know, we are actually open, they can come here and we will give it. Whatever the reason, as long as they want to know the information, we will serve according to the procedure of public information request".

Various efforts to improve financial governance is conducted in collaboration with PPATK and KPK, it also increases party's accountability and transparency so that party information can be easily accessed by the community. Those improvements are continuously conducting by PKS in order to respect society and increase the legitimacy and public trust to PKS. Gray, et al (1996) have argued that accountability as a legitimate effort enhances organizational and democratic transparency. It even must be a leading party in terms of spreading and competing in goodness (sabil bilkhairat). For example, as stated by the accounting and finance staff of the PKS when asked how his opinion related to the ICW study which states that PKS' Financial Statements is the best among nine political parties participating in the 2014 election and declared as the best party with governance and transparency. Here are the responses from PKS' Accounting and Finance Bureau staff:

"Surely...we have to be grateful for this achievement... this is something that reflects the professionalism... it means that community like ICW gives appreciation, of course that's a value, let it be the person who gives, but for us it has been PKS mandatory to compile a good financial statements. Other than a professional characteristic, we are not only a political party, but we are also a Dakwah Party, which means, working with ahsanu amala value is a must. So we have 2 values, the first value is the context as the dakwah party, ahsanu amala, in the reflection of the political party it means to become a professional. That in the context of the treasurer with good financial statement management is indeed the characteristic of the professionals we want to develop. And of course in many ways the other parties also have another portion (MGU)".

The statements above illustrate how the race in goodness has become a culture within the Dakwah Party. Similarly, when working and managing the party is done with the motivation and spirit of Ihsan, which is doing a job as well as possible, as beautiful as possible, and as perfectly as possible as a form of faith and love to Allah SWT. To manage a party with Ihsan spirit, to respect society, according to the PKS there are two important directions for PKS: Firstly, making a meticulous planning since it will decide the success of a planning. Secondly, in order to respect society, PKS can partner and cooperate with various elements of society, community organizations, other political organizations, even with the government as a form of fastabihul khairat. As stated by the Chairman of PKS' religious council as follows:

"In order to make a planning we must pay attention to the accuracy in various aspects. Being meticulous in understanding the function of planning in an organization and movement. Being meticulous in paying attention to the factors that determine the success of a plan. Being meticulous to compile stages process of planning. Being meticulous in taking into account the elements of planning preparation. Being meticulous in the continuity of a planning review. That accuracy leads to success and failure. Let us arrange a work plan based on the spirit of fastabiqul khairaat".

Institute of Internal Auditors (2006), stated that governance in a public sector organization included policy and procedure used to direct operational activity in order to guarantee the achievement of a goal and that operational activity are carried out ethically and responsibly. In the public sector, governance includes tools to achieve the intended 
purpose. According to the Australian National Audit Office (2003), governance in public sector organization aims to ensure that organization achieves overall results in such a way in order to increase trust in the organization, organizational decisions and organizational actions. Good governance focuses on two main requirements, namely performance and conformance. The purpose of GPG implementation in PKS is to further solidify the party's solidity, so that the party is able to perform its functions well, like functions of education, advocacy, and regeneration so good party credibility is established. Therefore, party legitimacy can be maintained, Suchman (1995) argued that maintaining legitimacy is much easier than obtaining or improving legitimacy.

Platform and Elements in Good Party Governance. Implementation of Ihsan spirit in realizing GPG was started with a solid foundation, namely: Paradigm of Dakwah Party, Basic Philosophy of PKS' Struggle whose nature is organizational values, PKS Policy Principles and Development Policy Platform which is PKS attitude toward development. Based on those basic values were then compiled the elements of governance, namely: Management System of Dakwah Party (SMPD), Strategic Planning (Renstra), and Annual Work Plan Budget (RKAT). Auditor General of British Columbia (2008) stated that governance refers to the structure and process where an organization is directed, controlled, and held accountable. Governance is a means to help the organization achieve its goals. Australian National Audit Office (2003) stated the purpose of governance is to ensure that the organization achieves overall results in such a way in order to increase trust in the organization.

The paradigm of a Dakwah Party is a theoretical framework and direction that combines the struggle of values (ideology) of Islam structurally and culturally for the realization of the objectives of the Dakwah Party. IFAC (2014) explained the basic principle of good governance, i.e. to behave with integrity, a strong commitment to ethical values and to respect for the rule of law. Islamic Dakwah according to the PKS is essentially a planned activity to transform individuals and society from the old tradition of life to a new one that reflects the spirit and teachings of Islam. The process of individual transformation is the formation of true Muslim person (syakhsiyyah islamiyah) done within the framework of social transformation. It boils down to the assurance of humanity in fulfilling the five primary needs of his life, i.e. the protection of his religion, soul, mind, wealth and his descendants in the United State of the Republic of Indonesia.

PKS Development Policy Platform conforms to the national development paradigm. This platform is a document that reflects the party's vision, mission, program and attitudes on various Indonesian issues. The platform becomes the main motivator and activator of the party's activities, and will make all Party's assets in all sectors of life, i.e. the third sector, public and private sector work in an integrated way, continuous, focused and directed so that limited party resources can be managed well to get results as expected and felt by sympathizers, constituents and society at large. The PKS considers that development must be based on three realistic thinking characteristics which are integral, universal, and total participation. That platform is to direct the organization's activities to be understood, as Suchman (1995) argued that an organization with cognitive legitimacy when its activities are understood, predicted, meaningful and interesting.

In operating the Basic Philosophy of Struggle and Development Policy Platform mentioned above, it should consider the following 10 (ten) policy principles: Al-Syumuliyah (complete and integral), Al-Ishlah (reformative), Al-Syar'iyah (constitutional), Al-Wasathiyah (moderate), Al-Istiqomah (commit and consistent), Al-Numuw wa al-athawwur (growing and developing), Al-Tadarruj wa Al-Tawazun (gradual, balanced, and proportional), Al-awlawiyat wal Ashlah (priority scale and benefit priority), Al-Hulul (solution), Al- Mustaqbaliyah (future orientation). Furthermore, the Basic Philosophy of Struggle and Development Policy Platform are embodied in the five-year Strategic Planning (Renstra) of the Party with the guidance of the Annual Work Plan Budget (RKAT) in realizing it. To ensure the performance of the party in accordance with the Renstra and the RKAT is required the Management System of the Dakwah Party (SMPD). 


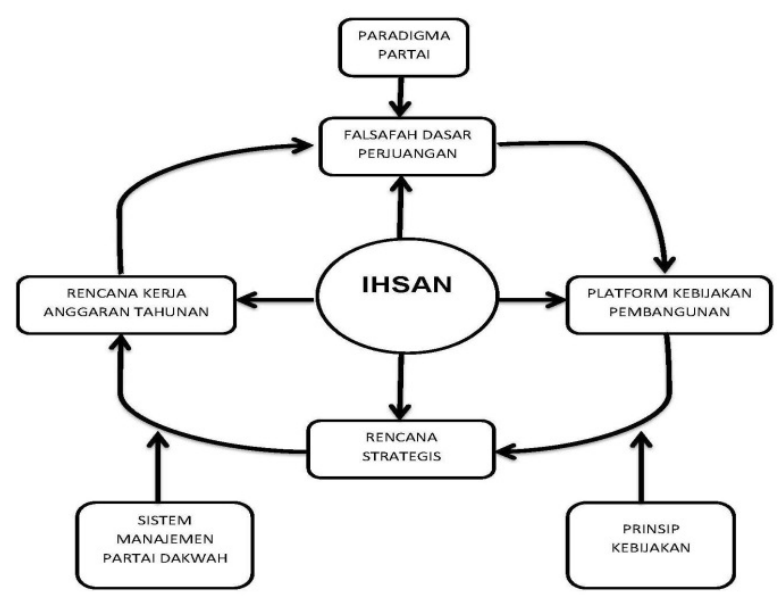

Figure 1 - The Essence of Good Party Governance in PKS

PKS' Strategic Planning is an instrument to direct its future journey, so that the steps taken are the best endeavors in accordance with ideological direction, organizational demands and availability of resources. Formally, Renstra is a managerial process to define the vision, mission, goals, objectives, strategy, policy direction, ultimately conical to the party's strategic program within a given period (5 years), which will determine the way in which resources are acquired, allocated, and managed power to achieve organizational goals. Renstra is compiled based on the understanding of the strategic environment both nationally, regionally and locally by taking into account potential, opportunities and constraints.

Briefly, PKS's renstra is a five-year national party program plan that is a consensus and a shared commitment of all party components in the context of achieving the vision and mission of the party. Process steps are based on the assumption of activities needed to ensure effectiveness (Scott, 2003). All components within the party body must make the Strategic Planning as a guide and the reference of its motion step, because the Strategic Plan binds all components of the party. The drafting of Renstra PKS during the 2015-2020 is done using benchmarking method from National Planning System and strategic management approach, which is adjusted to party condition. According to this method, the planning process undertaken covers a number of aspects. Firstly, the aspect of the flow or the drafting cycle. Secondly, the orientation aspect of the programming. Thirdly, the function aspect, and fourthly, the aspect of the service sector.

By combining those four aspects above, PKS expects the strategic program developed in this Renstra to encourage the party to manage various resources that are owned in a holistic, integrated and sustainable way to be happy and make positive changes in the future both inside the party and society, nation and country. As a result, the organization will get procedural moral legitimacy (Suchman, 1995). Here is the process of drafting Renstra spoken by the Secretary of Religious Council:

"There are nine (9) Basic Policies, later on will be explained to be this strategic plan (while showing the document of PKS' Strategic Planning).... actually, after the strategic plan there again... called as Annual Working Plan (RKT).... but we have not passed the name of the annual working plan, so endorsed by the Religious Council. In accordance with the Articles of Association of Chapter 7 of paragraph 14, one of the duties of the Religious Council is to determine the annual work program as well as the draft budget of the Party's income and expenditure (UWA)".

The PKS' Strategic Planning is implemented in an annual basis, beginning with the formulation of the Annual Working Plan (RKT). In relation to the implementation of the Strategic Planning through this RKT, there are several implementation rules that need to get the PKS attention so that the implementation of programs and activities run effectively and efficiently in generating output or outcome. Renstra's application into the annual programs and activities is guided by the rules: Synergistic, Integrative, Staged and Focused. PKS 
governance with the spirit of Ihsan as described above, in line with Australian Government (2007), Governance in public sector organizations includes a set of responsibilities and policies and procedures by agencies to provide strategic direction, to ensure objectives are achieved, to manage risks and to use resources responsibly.

The process of preparing RKT or more detailed RKAT initiated and derived from the strategic programs that have been included in the Strategic Planning, and then explained into activities for which each activity is made budget, as delivered by the Vice Chairman of PKS who oversee the process of preparing that RKAT:

"About how to prepare RKT, of course our CTR out of the program actually. There are 2 programs, i.e. strategic program and support programs. The support program is usually routine jobs. Strategic program..., this comes from the first mandate of the Religious council... nine other mandates are also from Religious Council. Downgraded to 14 policy directions, then to about 58 strategic programs. One strategic program can be 2, 3, even 4 activities, that is what makes the total activities so there are 614 activities. Well... out of these 614 activities, each budget is made up... the amount of activity and budget. Yes... because it is different... RKT's activity and budget is different from RKAT, RKT's activities is amounting to 614 (MAS)".

Those activities are proposed by every Field/Agency in the DPP, any commissions in MPP and every Institutional management/lajnah in DSP. All activities proposed by the DPP, MPP and DSP, will be reviewed by the Team Three, namely: Secretary-General Team, Treasurer Team, and Team of Planning Board. The Secretary-General team is tasked to ensure that the proposed activities are derived from the Munas Mandate, the Treasurer team obliges to observe in terms of budget and funding, and the Team of the Planning Board has the duty to view the activities as a whole. The result of the study from this Team Three becomes the RKAT document, which was then ratified in the Religious Council Assembly.

Management System of Dakwah Party (SMPD) aims to improve the performance and image of the Party. Within the Party's Strategic Planning, there are four stages of SMPD: Firstly, consolidation phase. This stage conducts the compilation of SMPD conception and guidance of SMPD level 1 and level 2 . Secondly, the strengthening stage with the standardization of SMPD organization management system by good governance. Thirdly, strengthening stage of organizational management system (SMPD) by good governance. Fourthly, evaluation phase which is a maknawiyah and suluk evalution, and HR's togetherness spirit of party structural, Renstra, Party conception, organizational management system (SMPD), network and party media. Here is an overview of SMPD submitted by informants from the head of the Performance Organization and Administration (OKA) bureau:

"During the management year of 2015-2020, there is a program that one of them is the implementation of Good Party Governance..., Mbak. Well then, one of those programs is management system of dakwak party... SMPD. We are here in the OKA bureau is as one of the responsible for the implementation of the program... strategic program for the implementation of GPG especially... its SMPD... you had already seen right that here we...hmmm... .make a kind of... to try to... we just conducted work meeting that discusses about arranging management system of party performance... SMKP... as... one of..."As the name implies... there are an organization control division, performance management division, and service and administration division. In management division, we will always monitor their progress by requesting their report. We just made a monthly report format from each field of agency (MAR)".

The implementation of SMPD in improving the performance and image of the Party is by establishing the bureau of Organizational Performance and Administration (OKA) with the structure under the Secretary General, OKA Bureau has three divisions, i.e. Organizational Control Division, Performance Management Division, and Services and Administrative Division. That OKA bureau as one of the responsibles for the implementation of all strategic programs that have been defined in the Strategic Planning. That OKA bureau also makes a guidance of Management System of Party Performance (SMKP), to monitor performance in the field of institution. How the achievement of targets progress in implementing strategic programs that have been defined in Renstra. From this monitor SMKP, we found there was a 
tone of evaluation and recommendations related to the implementation of strategic programs by the field of the agency. This structure also serves to maintain the legitimacy of the organization, which is called structural of moral legitimacy (Suchman, 1995)

The evaluation was here also related to its finances. Whether those programs have allocated funds under the 4E principle: Efficient, Effective, Economical, and Ethical. If it is not as planned, it will be recommended for improvement. To be clear, the OKA Bureau functions to ensure that all strategic programs that have been defined in the Renstra can run and to find out how far these programs effectively improve the performance of the Party. If there is a less effective program, that program will not proceed and will be replaced by a more effective new program. This evaluation is also very important to provide inputs in the compilation of next year's working plan, or next year's RKAT.

The practice of PKS governance as described above, is in conformity with the principles of good governance at public sector organizations formulated by UNDP (1997) including the community participation, enforcement of law supremacy, transparency, paying attention to the interests of stakeholders, consensus-oriented, equity, effectiveness and efficiency, accountability and strategic vision. Governance of PKS is also aligned with the six principles of good governance for public organizations by Independent Commission for Good Governance in Public Services (2004) includes: The focus is on organizational goals and outcomes for the community and public users; Working effectively in accordance with clearly defined functions and roles; Implementation of good governance values into the organization; Information retrieval, transparent decision making and risk management; Capacity building and organizational capability to be effective; Engage stakeholders and accountable.

\section{CONCLUSION}

PKS as the Dakwah Party should work and manage its party in accordance with the motivation and spirit of Ihsan which is doing a duty as well as possible, as beautiful as possible, and as perfect as possible as a form of faith and love to Allah SWT. Managing the party with the Ihsan spirit, according to PKS, there are two important directions for PKS to respect society: Firstly, making a careful planning; secondly, in order to respect society, it can partner and cooperate with various elements of society, community organization, other political organizations, even with the government as a form of fastabihul khairat. PKS is always improving itself which is reinforced by the announcement of Good Party Governance (GPG) in one of the formulated mission.

Implementation of Ihsan in realizing GPG PKS is started by a solid foundation, namely: Paradigm of Dakwah Party, Basic Philosophy of PKS whose nature is the values of organization, PKS Policy Principles and Development Policy Platform which is PKS' attitude toward development. Based on those basic values were then compiled the elements of governance, namely: Management System of Dakwah Party (SMPD), Strategic Planning (Renstra), and Annual Working Plan (RKAT).

Research limitations aiming to understand and describe the meaning of Good Party Governance using this ethnographic method are, during the process of data collection to explore the site of a relatively sensitive political party and to cover the awrah of organization, also the informants are very busy so have limited time and opportunity to provide information, explanations and discussions with researchers to the fullest. To overcome those limitations, the next researchers can conduct participating observations over a considerable period (more than the minimum recommended time of ethnographic method) by being a party member, so as to engage in party activities and establish more intensive communication with party elite and grassroots.

The implications of this study are in the theoretical realm as the development of the concept of good governance in political parties based on the spirit and values of the organization, in the practical realm as a comparison of good governance practice within political parties based on organizational values and in the policy realm as a matter of government consideration in reviewing and improving regulations related to Good Party Governance, by establishing a culture of good governance in political party organization. A 
further research can study the correlation between organizational culture within political party, good party governance, and organization legitimacy.

\section{REFERENCES}

1. Auditor General of British Columbia. 2008. Governance Good Practice Principles. Victoria: Auditor General of British Columbia.

2. Australian Government. 2007. Building Better Governance. Commonwealth of Australia.

3. Australian National Audit Office. 2003. Public Sector Governance vol.1. Canberra: ANAO.

4. Chikerema, A.F., and Chakunda, V. 2014.Political Culture and democratic Governance in Zimbabwe.Journal of Power, Politics \& Governance. Vol.2, No. 1, pp.55-56

5. Geertz, C. 1973. The Interpretation of Cultures: Selected Essays. New York.

6. Gray, R.O., and Adams. 1996. Accounting and Accountability: Changes and Challenges in Corporate Social and Environmental Reporting.Prentice-Hall. Europe. London

7. Independent Commission on Good Governance in Public Services. 2004. Good Governance Standard for Public Services. London: Hackney Press Ltd.

8. Indonesia Corruption Watch (ICW). 2013. Annual Report. Jakarta.

9. Institute of Internal Auditors. 2006. The Role of Auditing in Public Sector Governance.Florida: Institute of Internal Auditors.

10. International Federation of Accountants dan Chartered Institute of Public Finance and Accountancy. 2014. International Framework: Good Governance in the Public Sector. New York: IFAC.

11. Islam, S.S. 2016. Good Governance and Political Culture: Acase Study of Bangladesh. Intellectual Discourse.Vol 24, No. 2. Pp 245-271

12. Kasman, A. 2002, "Penyelenggaraan Pemerintahan Dalam Konsep Good Governance" Jurnal Meritokrasi Vol. 1 No. 1, Fakultas Hukum Universitas Hasanuddin, Makassar

13. Marzali, A. 1997."Kata Pengantar" dalam Metode Etnografi. James Spradley. Tiara Wacana.Yogyakarta.

14. Musa, A.K. 2016. Democracy, Party Politics and Good Governance: The Role of Electoral Management Bodies in Nigeria. International Journal of Public Administration and Management Research.Vol.3, No.3.

15. Raba, M. 2006. Akuntabilitas.Konsep dan Implementasi. UMM Press. 2006.

16. Rosenbaum, A. Good Governance. Accountability and the Public Servant. http://unpnlun.org/intradoc/group/pubkic/documents/nispaccc/unpan005698.pdf

17. Scott, W. R. (2003). Organizations: Rational, Natural, and Open Systems (5th ed.). New Jersey: Prentice Hall.

18. Shakil, Md.R.H., 2013. Political Parties and Good Governance: Bangladesh perspective. Journal of Humanities and social Science. Vol.8, No.5, pp: 37-45.

19. Sinclair, A. 1995. The Chameleon of Accountability: Forms and Discourses. Accounting Organization and Society.20 (2-3): 219-237.

20. Spradley, J.P. 1997. The Ethnographic Interview. Elisabeth M.Z. (penerjemah) Metode Etnografi. Tiara Wacana Yogya. Yogyakarta.

21. Stewart, J.D. 1984. The Role of Information in Public Accountability.in Hopwood A. \& Tomkins. C. (eds). Issues in Public Sector Accounting. pp. 13-34.

22. Suchman, M.C. (1995). Managing Legitimacy: Strategic and Institutional Approaches Academy of Management Review, 20(3), 571-610.

23. Tetlock, P.E., 2013. Accountability and Ideology: When left looks right and right looks left. Organizational Behavioral human Decision Prosesses.122: 22-35.

24. United Nations Development Programme. 1997. Governance for Sustainable Human Development. New York: UNDP.

25. Velayutham, S., and Perera. 2004. The Influence of Emotions and Culture on Accountability and Governance. Corporate Governance 4(1): 52-64.

26. Widodo, J. 2001.Good Governance; Telaah Dari Dimensi Akuntabilitas, Kontrol Birokrasi Pada Era Desentralisasi Dan Otonomi Daerah, Insan Cendekia, Surabaya.

27. World Bank. 1992. Governance and Development. Washington. 